\title{
ETHNIC AND RELIGIOUS DIVERSITY IN SARAWAK: PEACEBUILDING AMONG MUSLIM YOUTH
}

\author{
Sharifah Nooraida Binti Wan Hasan ${ }^{1}$ \\ Institute of Teacher Education Batu Lintang Campus Kuching, \\ Sarawak, Malaysia \\ Email:snwh79@yahoo.com.my
}

\begin{abstract}
The ethnic and religious diversity in Sarawak is unique among Malaysians. The need for tolerance and unity regardless of the existence of various ethnics and religions is the key to building peace in Sarawak. The state of unity in Sarawak is sustained with the role of Islam as the official religion, the constitutional monarchy, community structure, political will, social awareness, positive peace, economic stability and education for gender equality. Muslim youth in Sarawak are also playing roles in promoting peace through esteemed programmes in an effort to engage peacebuilding among youths. 'Islam is the way of life' continues to be the principle in engaging Muslim youth towards peace. The Institute of Teacher Education (ITE) Batu Lintang Campus in Kuching, Sarawak is one of the higher learning institutions in Malaysia that is engaging youth in promoting peace. ITE Batu Lintang Campus participated in colouring Malaysia with 'The Youth Peace Campaign' accompanied by 394 youth from all over Sarawak. This paper aims to share the roles and opinions of the Muslim youth towards peace in their diversified ethnic and religious community. Although ITE Batu Lintang Campus endorsed no specific course accentuating on peacebuilding education, the youth in the campus are still the main asset for promoting peace in ethnic and religious diversity.
\end{abstract}

Keywords: ethnic and religious diversity, peacebuilding, Muslim youths, state of unity, Sarawak

${ }^{1}$ The author is a lecturer at Research and Innovation of Teacher Professionalism Department, Institute of Teacher Education Batu Lintang Campus Kuching, Sarawak, Malaysia. Her academic research and publications focus on Islamic's education, teacher's education, women's rights education, peace studies and arabic language studies. The author would like to aknowledge the support from University of Malaya to sponsor this research-based article (GC001B-15HNE) and expresses her deepest grattitute. The warmest thanks are also extended to all assitance to the research project. The author would also like to credit the Annual International Conference on Islamic Studies (AICIS) 2017 organized by the Ministry of Religious Affair of the Republic of Indonesia in which the author was invited to present the paper. It was held in Jakarta on 22-25 November 2017. 


\section{INTRODUCTION}

Malaysia ranks 29th on the Global Peace Index (GPI) and is the fifth most peaceful country in the Asia Pacific region after New Zealand, Japan, Australia and Singapore (Beatrice, 2017). Sarawak is one of the thirteen states in Malaysia and is known as a beautiful and vibrant state with a soul of unity (Department of Information Malaysia, 2017). The phenomenal progress of peace in Sarawak has been built upon the foundation of unity and harmony among more than 30 ethnics groups with different religious, beliefs, customs and traditions (Sarawak Chief Minister's Department, 2013). Harmony and prosperity in Sarawak is also built upon the unity of diverse communities, like many tributaries feeding a mighty river as they flow in unison towards the sea. The convergence of people in Sarawak with diverse cultures and religions forms a common destiny of a harmonious and prosperous Sarawak (Sarawak Chief Minister's Department, 2013).

A Muslim community leader in Sarawak described its state of unity as being sustained with the role of Islam as the official religion, constitutional monarchy, structure of community, political will, social awareness, positive peace, economic stability and education for gender equality (Wan Hamid, personal communication, August 31, 2017). In other words, Sarawak's former and present Chief Minister brought about political stability and rapid progress to the state. Islam is the official religion, which with the power of constitutional monarchy unites all communities in Sarawak to live in harmony. Politic, social, economic and educational factors also contribute to a positive peace in Sarawak. This situation is not supprising as it also happens in other placess such Indonesia, Thailand and Brunei. In the case of Indonesia, especially in the eastern region, Taufani (2016) argues that the situation of the dakwah of Islam is related to the politics, and the relation is not static but rather then more dynamic following the context.

As far as Islam is concerned, such an honourable way of living is the spirit of peace that mentioned in Qur'an (Qur'an 6:82). The believers who worship Allah SWT and do not associate with Him are the people who have the peace and tranquillity of life and guided in the world and the hereafter (al-Mubarakfuri, 2000). Peace of mind is also a part of peace in our life. With peace of mind, we can do all things safely. A Muslim Chief Minister of Sarawak unites all communities under the jurisdiction of the constitutional monarchy as stated in Constitution of Malaysia. Islam is the religion of the Federation, but other religions may be practised in harmony and peace in any state in Malaysia. In addition to the practice of Islam elswhere, based on the view of Tariq Ramadhan, Abdulroya Panaemalae and Prasojo (2016) 
also explain that the Muslim world must be considering the other world in the effort of peacebuilding in this globe. The understanding between Islam and the West is an example of the phenomena that must be given attention seriously for the efforth of youth movement of peace.

\section{YOUTH AND PEACE: NEW APPROACHES}

In describing the formula used by Rasulullah SAW to establish peace after emigrated to Medina, al-Mubarakfuri (1987) mentioned that Rasulullah SAW united Muslims with aqidah, politic and Islamic systems. He shifted the view to establish the relationship with non-Muslim groups in Medina. His purpose was to bring peace, prosperity, goodness to the universal human, as well as restructuring the Medina district in a harmonious life. He set up the rules of tolerance that has never been enjoyed by community in Medina before. Rasulullah SAW made an agreement with non-Muslims and gave them a freedom to choose their own religion and financial dealing. This shows that the Prophet Muhammad SAW was using his practical wisdom to protect Medina and the Muslim community by taking good care of non-Muslims with prosperity. Rasulullah SAW was a great peaceful Muslim idol. Zayd Ibn Harithah was a youth in the Prophet Muhammad's SAW era whose maintained peace in joining the Mu'tah war who was commissioned and trained by Rasulullah SAW to become the youngest war warrior during that time (Al-Būtī, 1991).

Malala Yousafzai (2017) stressed in her speech that Islam is a religion of humanity, peace and prosperity. This youngest Noble Peace Prize winner shared that the best way to fight against terrorism and extremism is to educate the next generation with a quality education. The youth play an important role in spreading awareness and message of peace to the next generation. She was appointed the United Nation Messenger of Peace to promote girls' education through her voice in 2017.

Johan Galtung (1996) revealed that peace can be categorized as positive or negative. This prominent founder of peace defined the positive notion as the conservation of social relations, strengthening the social system that fulfil the needs of the population, and strengthening social activities to fulfil community needs. Negative peace refers to the absence of violence such that it can be prevented and stopped. Maintaining the peace from a state from war and conflict zones is a negative peace. Peace does not mean absence of any conflict, but rather that all conflicts are handled in a constructive fashion towards resolution. Johan and Malala had undergone some cruelty experiences in their childhood life that shaped their determination to work for peace. Experience based learning leads to support for maintaining a peaceful mind, life, and nation. 


\section{PEACEBUILDING AMONG MUSLIM YOUTHS: ITE BATU LINTANG CAMPUS EXPERIENCE}

In late 1941, most of the European officers during The Brooke Era in Sarawak, were rounded up by the Japanese and interned at Batu Lintang Camp, present known as ITE Batu Lintang Campus (Sarawak Government, 2017). The aura from the impact of the Japanese and Brooke site encourages the trainee teachers to contribute their ideas in engaging peace in ITE Batu Lintang Campus.

In April 2016, ITE Batu Lintang Campus organized 'The Youth Peace Campaign' accompanied by 394 youth from all over Sarawak. It was organized by 15 trainee teachers studying for their Bachelor of Education in Islamic Studies. Those 15 trainee teachers shared their roles and opinions towards peace in their diversified ethnic and religious community life. They organized the program as an effort to engage their role in maintaining and promoting peace among Muslim or non-Muslim youths. Although there is no specific course accentuating on peacebuilding education in the campus, but those 15 Muslim trainee teachers had spreading a message of peace through their effective activities in the peace youth campaign. The Muslim youth spread a message of peace to non-Muslim youth in Sarawak was accepted by the communities.

Their opinions in organizing the activities were based on the useful programs suitable for the youth. A memorable flash mob presentation was chosen to be the main activity in the peace campaign, in addition to a short talk show on 'Peace versus Violence' by invited panels. A flash mob refers to a large public gathering at which people perform an unusual or seemingly random act and then disperse (Oxford, 2017). This performance being chosen by the trainee teachers was intended for promoting awareness towards peace among the youth that participated in the campaign (Afiq, personal communication, April 1, 2016). Some of them were acting on the violence situation and war conflict happening in the present world. There were some participants who were trying to calm the situation and help each other.

Although there is no war or extreme conflict in diversified communities in Sarawak, the situation during the campaign influenced the youth which participated in these programs to feel the real situation through the flash mob presentation. The organizer shared that some of the participants cried while watching the flash mob presentation with a violence theme as contrasted with peace and harmony, including A Syrian attended the campaign (Adibah, personal communication, April 29, 2016). These feelings were shared by Johan (1996) and Malala (2017) who have undergone some cruel experiences in their life that determined them to engage for peace. 
YOUTH ROLES AND OPINIONS: TRAINEE TEACHERS PERSPECTIVES

Table 1 presents the role of Muslim's trainee teachers as an organizer of the peace campaign. The interviews with them revealed that the Muslim youth (6 out of 15) had agreed that they have a role in promoting peace programs through posters, pamphlets and social media including WhatsApp, Facebook, Twitter and Instagram. Meanwhile, two of them shared their future role in becoming educators providing an example of spreading positive thinking to the society. Nine of the trainee teachers had different ideas about their roles in promoting peace. They reflected their role in promoting peace by presenting flash mobs for attracting people, supporting programs, respecting each other, and spreading peace to communities with diverse ethnic backgrounds. They also shared their role in applying concern, cooperation, and relationships regardless of religion and customs. In their teaching life, they also thought that they should be providing awareness on domestic and international violence in school and continue promoting peace through novels, newspapers, or books that they will publish in the future.

Table 1 Trainee Teachers Roles as Youth towards Promoting Peace $(\mathrm{N}=15)$

\begin{tabular}{clc}
\hline No. & \multicolumn{1}{c}{ Role of Trainee Teachers as Youths } & Frequency \\
\hline 1 & $\begin{array}{l}\text { Promoting peace programs through posters, pamphlets } \\
\text { and social media (WhatsApp, Facebook, Twitter and Insta- } \\
\text { gram) }\end{array}$ & 6 \\
$2 \quad \begin{array}{l}\text { Becoming educators who can be an example in spreading } \\
\text { positive thinking to the society }\end{array}$ & 1 \\
3 & $\begin{array}{l}\text { Promoting peace by presenting flash mob show adapted } \\
\text { through real situations }\end{array}$ \\
$4 \quad \begin{array}{l}\text { Adopting tolerance and respecting each other although in a } \\
\text { different religions and cultures }\end{array}$ & 1 \\
$5 \quad \begin{array}{l}\text { Supporting peace program } \\
6\end{array}$ & $\begin{array}{l}\text { Spreading peace to the communities } \\
\text { Applying their concern to each other }\end{array}$ \\
$8 \quad \begin{array}{l}\text { Performing a show that can attract people to peace pro- } \\
\text { gram }\end{array}$ & 1 \\
$9 \quad \begin{array}{l}\text { Establishing cooperation and relationships in implement } \\
\text { things together regardless of religion and customs }\end{array}$ & 1 \\
10 & $\begin{array}{l}\text { Shall providing awareness on domestic and internation- } \\
\text { al violence in school and bring their students to think of } \\
\text { appropriate action to be taken }\end{array}$ & 1 \\
11 & $\begin{array}{l}\text { Promoting peace programs in the novel that I wrote either } \\
\text { in the newspapers or books }\end{array}$ & 1 \\
\hline
\end{tabular}


Table 2 presents the opinion of Muslim trainee teachers as youth engaging in a peace campaign. The interviews revealed that the Muslim youth (8 out of 15) suggested that awareness should be provided to Malaysian communities on the issue of current oppression inside and outside Malaysia through their peace programs. They suggested that the peace campaign be conducted annually. Meanwhile, five of them suggested to give awareness to the public about the importance of maintaining peace in a country; while two of them felt deep gratitude towards the peace in their country. Seven of the trainee teachers were concerned about their role in creating peace, demonstrating the challenges in achieving universal peace, spreading the message of peace, and preparing a defence of and love for peace of our nation until next generation, especially among youngsters. They also agreed that the peace program is a great program in promoting peace and stressed their concern in appreciating the struggles of the warriors of the past.

Table 2 Trainee Teachers Opinions as Youth towards Promoting Peace (N=15)

\begin{tabular}{clc}
\hline No. & Opinion of Trainee Teachers as Youths & Frequency \\
\hline 1 & $\begin{array}{l}\text { Provide awareness to Malaysian communities on the issue } \\
\text { of current oppression inside and outside Malaysia through } \\
\text { peace programs annually/more often }\end{array}$ & 8 \\
$2 \quad \begin{array}{l}\text { Giving awareness to the public about the importance of } \\
\text { maintaining peace in a country }\end{array}$ & 2 \\
$3 \quad \begin{array}{l}\text { Deep gratitude towards the peace in the country } \\
4\end{array}$ & $\begin{array}{l}\text { Youth need to play a role in creating peace in their life envi- } \\
\text { ronment }\end{array}$ & 1 \\
$5 \quad \begin{array}{l}\text { Demonstrate the challenges that the world faces in achiev- } \\
\text { ing universal peace }\end{array}$ & 1 \\
$6 \quad \begin{array}{l}\text { Spreads the message of peace } \\
7\end{array}$ & $\begin{array}{l}\text { Prepare for the defence of the nation until the next genera- } \\
\text { tion }\end{array}$ & 1 \\
$8 \quad \begin{array}{l}\text { Peace program is great for promoting peace to the present } \\
\text { society }\end{array}$ & 1 \\
9 & $\begin{array}{l}\text { To build a spirit of love for peace especially for young gen- } \\
\text { erations }\end{array}$ & 1 \\
10 & To appreciate the struggles of the warrior in the past & 1 \\
\hline
\end{tabular}

Why should Muslim youth be taught and remain aware about Islam and peace? What are the most appropriate activities and approaches for spreading a message of peace among youth? Can Malaysian youth engage themselves in promoting and maintaining peace while there was no war? Should Muslim 
youth engage in peace building? These questions are a serious challenge to scholars, educators, policy makers, curriculum specialists and Malaysian public. The task of maintaining peace includes developing educational awareness among the next generation of the true nature of peace building and its roles in the world. The perception that Islam is linked with terrorism, war and violence should be smoothly avoided. A positive peace in our lifestyle nowadays, encompassing good social relations and strengthened social systems and activities, should be brought up and declared as a component of peace in our country (Johan, 1996).

\section{CONCLUSION}

As a conclusion, it is imperative that the task of maintaining peace provides a learning environment as well as motivate the Muslim youth in engaging peace. Most importantly, roles of trainee teachers in providing awareness, supporting, promoting and spreading message of peace has become the key factor for achieving peacebuilding among youth in their diversified ethnic and religious community. Although ITE endrosed no specific course accentuating on peacebuilding education, the youth in the campus are still the main asset for promoting peace through their appropriate approach and programme in Sarawak.

\section{BIBLIOGRAPHY}

Abdulroya Panaemalae, A., \& Prasojo, Z. (2016). Islam and the West: Tariq Ramadan and the Discourse of Religion of Peace for a Global Understanding. Al-Albab, 5(2), 237 - 250. doi:https://doi.org/10.24260/alalbab.v5i2.507

Al-Būtī, M.S.R. (1991). Fiqh al-Sìrah al-Nabawī. (11th ed.). Beirut: Dār al-Fikr al-Macāsir.

Al-Mubārakfūrī, S.R. (1987). Al-Rahīq al-Makhtūm. Al-Mansūrah: Dar al-Wafa' li al-Tiba' wa al-Nasr.

. (2000). Al-Misbāh al-Munīr fì tahzīb Tafsir Ibn Kathīr. Riyadh: Darul al-Salām.

Beatrice, N.J. (2017, June 2). Malaysia ranks 29th on the Global Peace Index. New Straits Times. Retrieved from http://www. nst.com.my

Department of Information. Ministry of Communications and Multimedia Malaysia. (2017). States in Malaysia. Retrieved from http:// pmr.penerangan.gov.my 
Flashmob. (2017). In oxforddictionaries.com. Retrieved from https://en.oxforddictionaries.com/definition/flash mob

Galtung, J. (1996). Peace by Peaceful Means: Peace and Conflict, Development and Civilization. London: SAGE Publications.

Malala Yousafzai Biography.com. (2017, Oktober 17). Malala Yousafzai, Women's Rights Activist, Children Activist. Retrieved from https://www.biography.com/people/malala-yousafzai-21362253.

Sarawak Government. Sarawak State Secretary Office. (2017). The Japanese Occupation. Retrieved from http//www.sarawak.gov.my

State Implementations Motnitoring Unit, Sarawak Chief Minister's Department. (2013). Sarawak 50 Golden Years of Harmony and Prosperity. Kuching: Chief Minister's Department Sarawak.

Taufani, T. (2016). Indonesian Islam in Religious and Political Struggle Discourse. Al-Albab, 4(1), 101 - 120. doi:https://doi.org/10.24260/alalbab. $\underline{\mathrm{v} 4 \mathrm{i} 1.280}$ 